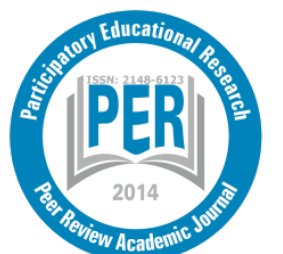

Participatory Educational Research (PER)

Vol. 7(2), pp. 164-182, August 2020

Available online at http://www.perjournal.com

ISSN: 2148-6123

http://dx.doi.org/10.17275/per.20.27.7.2

\title{
Diagnosing Students' Misconceptions of Astronomy Through Concept Cartoons
}

\author{
Seçil Serttaş \\ Department of Mathematics and Science Education, Alanya Alaaddin Keykubat University, \\ Alanya/Antalya, Turkey, ORCID: 0000-0002-0940-1287
}

\begin{tabular}{|c|c|}
\hline \multicolumn{2}{|c|}{$\begin{array}{c}\text { Ayşe Yenilmez Türkoğlu* } \\
\text { Department of Mathematics and Science Education, Alanya Alaaddin Keykubat University, } \\
\text { Alanya/Antalya, Turkey, ORCID: 0000-0002-1981-2813 }\end{array}$} \\
\hline Article history & The purpose of the study was to diagnose students' misconceptions of a \\
\hline $\begin{array}{l}\text { Received: } \\
23.01 .2020\end{array}$ & number of basic astronomy concepts, namely, the Universe, the Sun, \\
\hline $\begin{array}{l}\text { Received in revised form: } \\
28.04 .2020\end{array}$ & $\begin{array}{l}\text { students. Data were collected through concept cartoons and interviews. } \\
\text { In the concept cartoons prepared for each concept, there were four }\end{array}$ \\
\hline $\begin{array}{l}\text { Accepted: } \\
04.05 .2020\end{array}$ & $\begin{array}{l}\text { expressions, one of which is a scientific judgment, while the others were } \\
\text { misconceptions. Students were asked to choose one of these expressions }\end{array}$ \\
\hline Key words: & and explain why s/he thinks in that way. After the analysis of concept \\
\hline $\begin{array}{l}\text { Misconception, } \\
\text { basic astronomy concepts, } \\
\text { universe, } \\
\text { sun, } \\
\text { comet, } \\
\text { constellation, } \\
\text { concept cartoon, } \\
\text { science learning. }\end{array}$ & $\begin{array}{l}\text { cartoons, semi-structured interviews were conducted with five of the } \\
\text { students who were found to hold misconceptions. Findings of the study } \\
\text { showed that students held several misconceptions on the concepts being } \\
\text { studied. Students had misconceptions mostly about comets and they had } \\
\text { limited understanding about constellations. Defining a comet as an } \\
\text { image of a dying star falling from the sky was quite common among the } \\
\text { students, and the number of students who defined constellations as a } \\
\text { group of stars connected by lines among them was considerable. The } \\
\text { findings of the study also showed that concept cartoons are functional } \\
\text { tools for detecting misconceptions. }\end{array}$ \\
\hline
\end{tabular}

\section{Introduction}

Astronomy, being the oldest of all sciences, was born in response to two basic characteristics of human nature: the need to explore and the need to understand (Chaisson \& McMillan, 1999). In fact, since the earliest times, human being sought answers to questions about the nature and the universe. Universe is simply defined as the integration of space, time, matter, and energy whilst astronomy is basically the study of universe (Chaisson \& McMillan, 1999). Early civilizations resorted to astronomy for religious, mythological, and astrological purposes, as well as for keeping the track of time, doing agriculture, and orienting the cities. Thusly, ancient astronomical work included a careful observation of the sky, naming and plotting the positions of the bodies, and integrating this knowledge into religion and astrology. Aristotle's geocentric view of the universe, for example, took deep roots in Christian theology,

\footnotetext{
* Correspondence: ayse.yenilmez@alanya.edu.tr
} 
and it became a doctrine of religion as much as being a conceptualization of natural philosophy. In the $16^{\text {th }}$ century, beginning with Copernicus who introduced the heliocentric theory despite the risk of Church's disapproval, the rebirth of astronomy began. Pointing his telescope into the sky for the first time, Galileo discovered that there were beings in the Solar System that did not revolve around the Sun. Kepler, a contemporary scholar, introduced a number of laws that describe the orbits of the planets revolving around the Sun. Finally, on Galileo's work, Newton explained the rotating motion of the planets with a force named gravitational force, in the $17^{\text {th }}$ century.

Since the above briefly mentioned renaissance movements, astronomy has made long steps forward. However, astronomy education does not date back that far. To cite an example, in United States, astronomy education was not widely included into secondary science curricula until after Soviet Union's launch of Sputnik in 1957 (Marche, 2002). This action brought science education into the forefront and reformist actions including reconstruction of science curricula, organization of scientific meetings, and improvement of science materials, laboratories, supplementary materials and others with the help of great financial support took place. Together with the United States, many countries restructured their science curricula in order not to fall behind. This process started from the 1970s and continued until today. Adams and Slater (2000) described the progression of astronomy concepts in the United States in relation to the National Science Education Standards (1996). According to the NSES (NRC, 1996), students at grade K-4 are expected to know the properties, locations, and motions of the objects in the sky from a geocentric perspective, while students at grades 5-8 should develop a heliocentric solar system understanding, and comprehend day-and-night, seasons, eclipses, and lunar phases and define gravity as the force holding people to Earth's surface and causing planets to orbit in circular orbits. At grades 9-12, on the other hand, astronomy objectives go beyond the solar system and focus on the observation, origin, evolution, and characteristics of the Universe.

In Turkey, science education starts at grade 3. Grades 3 and 4 are included in elementary education, while grades 5-8 are a part of middle school education. The vision of the science curriculum for all grades is to educate all students as scientifically literate citizens. Among the main objectives stated in the curriculum is to raise knowledgeable students in astronomy, biology, physics, chemistry, earth and environmental sciences, and science and engineering applications. To achieve this objective alongside the others, science education at each grade is organized under numerous subject areas including "the Earth and the Universe", "living things", "physical phenomena" and "the matter and its nature", and the first unit of each grade began to be selected from the Earth and the Universe subject area after the changes occurred in science curriculum in 2018 (MoNE, 2018) causing the topic of astronomy to gain more attention. Students at elementary school (grades 3 and 4) are expected to comprehend the shape, layers, and the motions of the Earth (see Table 1). Students at middle school, on the other hand, should describe the shapes, structures and properties of the Moon and the Sun, explain the phenomena of day-and-night, and seasons, eclipses, and lunar phases, also know the elements of the solar system and basic space research (see Table 1). 
Table 1. Astronomy topics in current science education curriculum (MoNE, 2018) in Turkey

\begin{tabular}{ll}
\hline Grade level & Astronomy topic: \\
\hline 3 & The shape of the Earth \\
& The structure of the Earth \\
& The structure of the Earth's crust \\
& Motions of the Earth \\
The structure and the properties of the Sun & The structure and the properties of the Moon \\
& Motions and the phases of the Moon \\
& The relative motions of the Earth, Sun and Moon \\
& The Solar System \\
& Solar and Lunar eclipses \\
6 & $\begin{array}{l}\text { Space research } \\
\text { Beyond the Solar System: Celestial bodies }\end{array}$ \\
7 & Formation of seasons \\
& Air movement and climate
\end{tabular}

In order to educate students who are scientifically literate; critical thinkers and conscious individuals who do not associate scientific phenomena with supernatural powers, a great emphasis on astronomy education is to be put. In addition, since established illusions and ideologies are resistant to change in the later stages of education, it should be reiterated here that astronomy should take its own place in education programs to be able to ensure the learning of scientific concepts accurately (Taşcan \& Ünal, 2015). Moreover, to assure quality astronomy education in upper grades, the importance of astronomy as an essential part of science education should be recognized (Adams \& Slater, 2000). Yet, astronomy concepts tend to be misunderstood by a fair number of students. Students actually develop conceptions about natural phenomena, including astronomy, before learning science at school; and in some cases, there are significant differences between their scientific conceptions and conceptualizations through school science education (Driver, Squires, Rushworth \& Wood-Robinson, 1994).

Concepts are defined as vehicles by which one interprets the world (Posner, Strike, Hewson, \& Gertzog, 1982). They are fundamental for thinking. However, some of these thinking systems that are used to make sense of the world may be wrong or incomplete (Mestre, 1987). In the past few decades, several studies have been conducted with the aim of investigating and describing the aspects of students' understanding of scientific concepts. Among these concepts are cell biology (Dreyfus \& Jungwirth, 1988), photosynthesis (Bell, 1985; Haslam \& Treagust, 1987; Waheed \& Lucas, 1992), genetics (Lawson \& Thompson, 1988; Lewis, Leach, \& WoodRobinson, 2000; Pashley, 1994), ecology (Griffiths \& Grant, 1985; Kinchin, 2000; Munson, 1994), respiration (Sanders, 1993; Seymour \& Longden, 1991), classification (Trowbridge \& Mintzes, 1988), mechanics (Oliva, 1999, 2003), food (Lee \& Diong, 1999), diffusion and osmosis (Odom \& Barrow, 1995), the circulatory system (Yip, 1998), and energy (Boyes \& Stanisstreet, 1991). The findings of these studies revealed that students have many misconceptions about such science concepts.

Misconceptions are alternative conceptions that differ from accepted scientific knowledge (Anderson, Fisher \& Norman, 2002) and it was demonstrated that many misconceptions were already existing before formal teaching of the relevant topic began (Seymour \& Longden, 1991). Everyday experiences, unscientific use of everyday language, incorrect concept formation during formal schooling through teachers or textbooks influence the development of such misconceptions (Sanders, 1993). As a discipline, astronomy holds the biggest pool of misconceptions in science. Although the amount of research in astronomy education is limited compared to conceptual research in science education, related research shows that students have 
plentiful misconceptions in astronomical concepts like moon's rotation and phases, eclipses, seasons, day-and-night cycle, gravity, and celestial bodies including comets, constellations, stars, planets, including the Sun and also the Universe (Ekiz \& Akbaş, 2005; Göncü, 2013; Korur, 2015; Trumper, 2000).

So as to be able to probe students' conceptual understanding, researchers employ a variety of instruments. Among them are diagnostic tests (Sadler, 1998; Trumper, 2000; Zeilik, 2002; Zeilik, Schau, \& Mattern, 1998), open-ended questions (Frede, 2006), interviews (Albanese, Danhoni Neves, \& Vicentini, 1997; Kikas, 1998; Treagust \& Smith, 1989; Trundle, Atwood, \& Christopher, 2002), model demonstrations (Atwood \& Atwood, 1996; Jones, Lynch, \& Reesink 1987; Nussbaum, 1979) and drawings (Hannust \& Kikas, 2007; Koca, 2019). Objective tests work well for assessing conceptual understanding in large populations and interviews are informative means of examining a small number of students' understanding. In this study, a rarely referred probe; concept cartoons were used to diagnose students' misconceptions about basic astronomical concepts. These are supposed to make students' ideas more accessible to teachers, as well as researchers (Keogh \& Naylor, 1999).

Concept cartoons are originally developed by Keogh and Naylor (1999) and are used in science education to identify misconceptions about concepts. They are different from the known humorous cartoon format by presenting a multiple-choice question yet unlike the regular form, they integrate written texts in dialogue form with a visual representation of a familiar believable context (Keogh \& Naylor, 1999). In other words, in a concept cartoon, a group of characters are engaged in a dialogue, where alternative ideas including scientifically acceptable ones are presented in the form of speech bubbles. Since some of the statements in the speech bubbles contain alternative ideas about the scenario situation, concept cartoons are an effective method in determining misconceptions of the student. Science education researchers who use concept cartoons emphasize that in-class use of the method is highly successful (Keogh \& Naylor, 2013).

In light of these facts, the purpose of this study was to diagnose students' misconceptions about a number of basic astronomy concepts i.e. the Universe, the Sun, Comets and Constellations through concept cartoons and interviews. As mentioned earlier in the text, astronomy education began to take place in the first units of the science education program in Turkey (MoNE, 2018), and it is again on the agenda of researchers. In Turkey, there are studies examining students' understanding of astronomy (i.e., Bostan, 2008; Güneş, 2010; İyibil, 2010; Kanl1, 2014; Kaplan, 2011; Korur, 2015; Kurnaz, 2012; Kurnaz \& Değirmenci, 2012; Sezen, 2002) but studies examining understanding through concept cartoons is relatively rare (Arıkurt, 2014; Demir, 2008; Kurnaz, Bozdemir, Altunoğlu \& Çevik, 2016). It is undeniable that there is still a need to do further studies to determine the misconceptions that students have and to replace the misconceptions with scientific ones. This study, therefore, intends to answer the question: "What are seventh grade students' misconceptions about basic concepts of astronomy?" An investigation of students' understanding in astronomy is expected to be valuable to teachers, researchers, writers, and program developers. It is hoped that the findings of this research will shed light to the ways to detect and eliminate student misconceptions and to develop a scientific understanding instead. 


\section{Method}

\section{Design of the study}

The study was designed as mixed method research. Mixed method research is defined as the research in which the researcher combines quantitative and qualitative research techniques, methods, approaches or concepts in a single study or related studies (Onwuegbuzie \& Leech, 2005). In this study, sequential explanatory design, which is one of the mixed method research, was employed. The sequential descriptive pattern is the collection of quantitative and then qualitative data in a sequential stage in a study. After the quantitative data is collected and analyzed, the research is expanded with qualitative data (Ivankova, Creswell \& Stick, 2006). That is to say, the first step of the research is quantitative, and the process continues with the qualitative step. The quantitative data constituting the main framework of the research are analyzed and qualitative processes are designed and applied based on the results obtained from the findings.

\section{Participants}

This study confined itself to offering a number of astronomy concept cartoons and investigating the misconceptions of students in Alanya district of Antalya, Turkey. The population of the study was composed of all $7^{\text {th }}$ grade students in the public schools in Alanya in the 2018-2019 academic year. The sample of the study, on the other hand, consisted of 110 conveniently selected students (46 males, 64 females) from two different public schools, one from rural $(n=60)$ and the other from urban $(n=50)$ area. Seventh graders were of interest in this study because students at this grade get familiar with the related astronomy concepts through the education they receive. After the collection and analysis of quantitative data from this sample, students holding misconceptions were identified and qualitative data were collected from five conveniently selected students. Interviews were done with five students as additional participants no longer provided any additional insights. To put it in a different way, saturation; a central phenomenon to qualitative sampling, is attained with these students. Saturation is the point in data collection process where no new/additional data emerges from further participants to enable the development of the properties of the concerned subject (Glaser \& Strauss, 1967).

\section{Data collection}

With a view to diagnosing seventh graders' understandings of basic astronomy concepts, first, four concepts from the first unit of the seventh-grade science curriculum (that is, "The Solar System and Beyond") were chosen. The concepts are the Universe, the Sun, Comets and Constellations. The related literature suggests that these concepts are among the basic astronomy concepts in which students have difficulty learning and have misunderstandings. According to the national curriculum, after completing this unit, students are expected to explain the concepts of the Universe and star and become aware of the process of the formation of a star. In the preparation of the concept cartoons, these objectives in the curriculum were taken into consideration to ensure the content validity, and the expressions (scientific expressions and misconceptions) in the speech bubbles were chosen from the research findings in the related literature. The concept cartoons were then sent to four science education professionals (one professor, one associate professor, and two assistant professors) to receive expert opinion. Feedback of the professionals included suggestions about language compatibility and face validity. The necessary arrangements were carried out in line with the feedback and the concept cartoons were finalized. In the concept cartoons prepared for each concept, there were four expressions in speech bubbles indicating four different ideas. Only one 
of these expressions included a scientific judgment, while the others included misconceptions and unscientific views taken from the related literature. Students were asked to choose one of the ideas and explain why s/he thinks in the same way with this provided idea in the concept cartoon. The aim was to understand the reasoning behind their choices.

In the second step of the study, semi-structured interviews were conducted with some $(n=5)$ of the students who were found to have misconceptions. Interviewing step started with one student who had misconceptions and was convenient to be reached. Then, the second student was selected in the same way and this process continued till the fifth student. Interviewing stopped with the fifth student since based on the data gathered from the interviews, the researchers realized that students provided no new or additional information. Semi-structured interviews provided researchers with deep insights into the topic through asking probing questions. In this study, students were asked the basic questions: "What do you know about the Universe/Sun/ comets/constellations?" together with the probing questions like "Can you tell me more about ...?, Why do you think so?, Do you mean ...? , and so on. The aim was to gain detailed information about the concepts and misconceptions. The interviews took about 8-10 minutes and were recorded by a voice recorder which were then transcribed verbatim for analysis.

In each step of data collection, students were made aware of the purpose of the process. Their participation in the study was voluntary. Students were informed that they were free to withdraw their participation at any time of the study without any unfavorable consequences. In order to ensure the confidentiality, any identifying information was not made available to anyone but the researchers of the study, and such information was also excluded in reporting the findings. Interviewed students, for example, are represented as S1 for the first student, S2 for the second student and so on.

\section{Analyses of data}

\section{Analysis of Concept Cartoons}

Data obtained from the concept cartoons were analyzed descriptively based on the scoring rubric developed by Kusumaningrum, Ashadi, and Indriyanti, (2018) for the purpose of evaluating students' understanding levels. The scoring rubric is given in Table 2 (Kusumaningrum et al., 2018).

Table 2. Categorization of conceptual knowledge levels (Kusumaningrum et al., 2018)

\begin{tabular}{ll}
\hline Answer & Category \\
\hline Correct answer + Correct explanation & Understanding \\
Correct answer + Partially correct explanation & Partial understanding \\
Correct answer + Wrong explanation & Misconception \\
Wrong answer + Correct explanation & Misconception \\
Wrong answer + Wrong explanation & Not understanding \\
\hline
\end{tabular}

As shown in Table 2, choosing the correct answer (idea) and providing a correct explanation for the choice constitutes 'Understanding' category, while correct answer and partially correct explanations such as missing information or stating agreement with the opinion constitutes 'Partial understanding'. Choosing a correct answer but providing a wrong explanation or choosing a wrong answer but providing a correct explanation means misconception. Lastly, choosing a wrong answer and not providing an explanation (leaving the place for specifying a reason blank) or giving irrelevant or unscientific explanation indicates there is no understanding. 
The correct, partially correct and incorrect student explanations were categorized in the following way:

- Correct explanation: Includes all aspects of the scientific explanation for the concept being asked.

- Partially Correct explanation: Covers explanations that contain one or more aspects of the scientific explanation for the concept being asked, but not all the aspects.

- Wrong Explanation: Although it constitutes an explanation for the concept asked, it contains explanations that reflect misconceptions that do not comply with scientific facts.

A sample coding for the correct, partially correct, and wrong explanations is given in Table 3.

Table 3. Sample coding for the explanations

\begin{tabular}{ll}
\hline Explanation & Sample excerpts \\
\hline "The Universe is a space containing galaxies, planets, stars, \\
meteors, comets, and all other celestial bodies." \\
"The sun is a star but not the hottest one. There are hotter stars \\
than the Sun, too." \\
"Comet is not a star. It reflects light from the Sun. It also contains \\
frozen ice, dust and gas." \\
"Constellations are star patterns that appear to be together when \\
viewed from the Earth." \\
"The Universe consists of Mercury, Venus, Earth, Mars, Jupiter, \\
Saturn, Uranus, Neptune and the Sun." \\
"The Sun is a star. It is the hottest star." \\
"Comets are very fast moving celestial bodies." \\
"Constellations are star patterns formed by the merging of stars.", \\
"The Universe is the planet Earth itself." \\
"The Sun is the hottest planet." \\
"Comet is the image of a falling star." \\
"Constellation is a collection of stars moving together."
\end{tabular}

After categorizing the answers and explanations of the students, the percentages of the category of the related concept was calculated as follows (1).

conceptual knowledge level $\%=\frac{\text { number of students in each category }(f)}{\text { total number of students }(N)} \times 100$

\section{Analysis of interviews}

Content analysis was used in the analysis of semi-structured interviews conducted with some of the students holding misconceptions. Content analysis is a qualitative method for identifying, analyzing, and reporting repetitive patterns within a data set (Sharp \& Sanders, 2019). Using content analysis, researchers can make inferences about the massages within the data. In this particular study, students were asked to answer a number of in-depth open-ended questions during the interviews, and after the transcription of the interviews, transcripts were coded separately by the researchers of the study. The percentage of agreement between the codes was calculated according to the formula offered by Miles and Huberman (1994), which is, Reliability Percentage $=$ Agreement $/($ Total Agreement + Disagreement $)$, and it was found as .81. 


\section{Findings}

In this section, findings are presented based on the concepts investigated.

\section{Findings about the concept of the Universe}

The concept cartoon about the Universe concept is given in Figure 1.

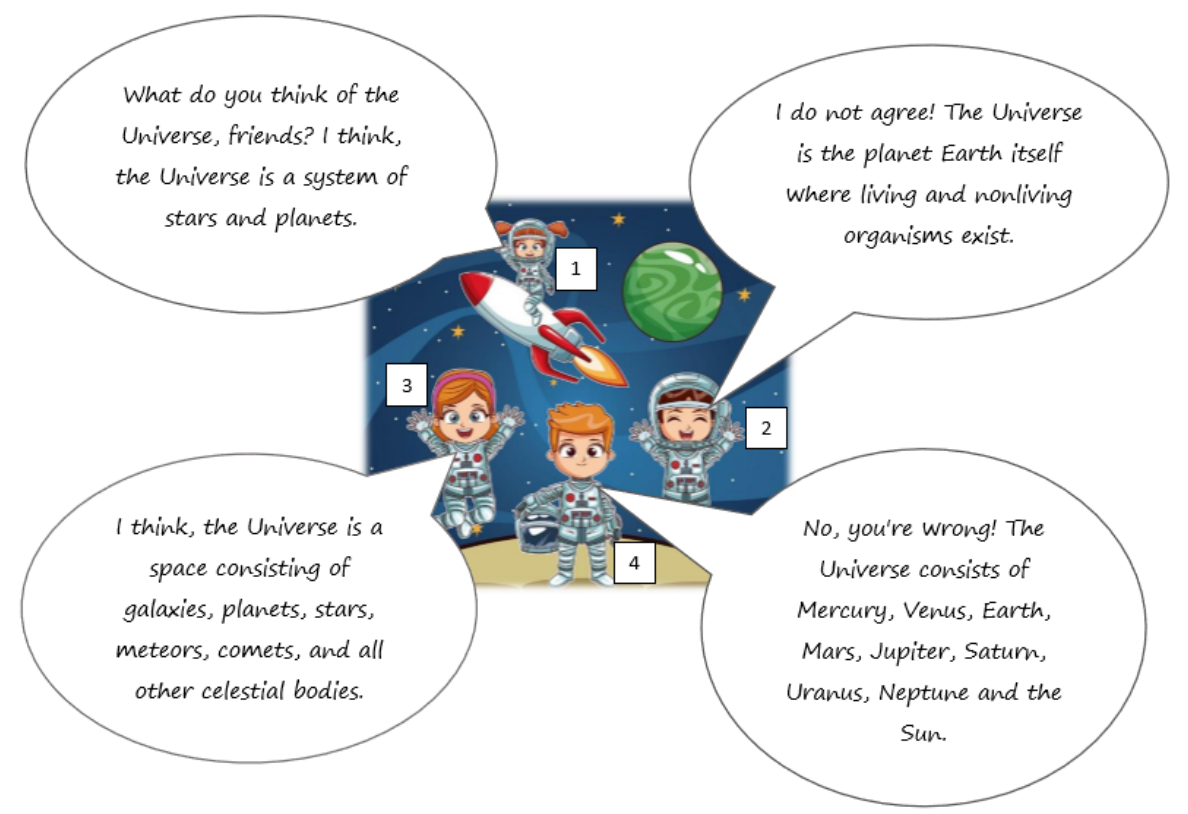

Figure 1. The concept cartoon about the Universe concept

In the concept cartoon about the Universe concept (Figure 1), only the $3^{\text {rd }}$ expression was scientific, whereas others $\left(1^{\text {st }}, 2^{\text {nd }}\right.$ and $\left.4^{\text {th }}\right)$ spanned misconceptions. Students' conceptual knowledge levels identified by the concept cartoon are given in Table 4.

Table 4. Students' conceptual knowledge levels about the Universe concept

\begin{tabular}{lll}
\hline Answer & $\mathrm{f}$ & $\%$ \\
\hline Understanding (Correct answer + Correct explanation) & 46 & 41.81 \\
Partial understanding (Correct answer + Partially correct explanation) & 20 & 18.18 \\
Misconception (Correct answer + Wrong explanation) & 19 & 17.27 \\
Misconception (Wrong answer + Correct explanation) & 7 & 6.36 \\
No understanding (Wrong answer + Wrong explanation) & 18 & 16.36 \\
\hline
\end{tabular}

As seen in Table 4, 41.81\% of the students selected the correct answer and brought out a scientific explanation by describing the universe as a space consisting of celestial bodies like galaxies, stars, meteors, comets, and others. $18.18 \%$ of the students, on the other hand, turned to incomplete or short explanations despite specifying the correct response. Additionally, as seen in Table $4,16.36 \%$ of the students marked a wrong expression in the concept cartoon, and interestingly did not state the reason behind their thought, or simply responded as "this is because they learned it in this way at school". It was found that $23.63 \%$ of the students had misconceptions about the concept of the universe.

The written explanations and interviews showed that, among the students having misconceptions, a considerable number $(n=17)$ defined universe as emptiness or infinity outside the Earth, while some defined Earth as the center of the Universe $(n=12)$ and some others 
defined the Earth as the universe itself $(n=11)$. It was observed in the interviews that students featured universe as black, glittering, expanding or round-like. Some excerpts from their written explanations (Wr. Exp.) to open ended questions and interviews (Int.) are as follows:

"It (the Universe) is the place outside the Earth. It's a big emptiness." [Wr. Exp., Female]

"It (the Universe) is an emptiness; an endless place with no atmosphere." [Wr. Exp. \& Int.-S4, Female]

"There is only one Earth to live, there is no life in the Universe. The universe is an emptiness and an endless place." [Wr. Exp., Male]

"The Earth is our universe." [Wr. Exp., Female]

"The Earth is at the center of the Universe." [Wr. Exp., Female]

"The Universe is the Earth. There is life and water in our Universe but not in other places. Maybe Mars, but we don't know that right now. " [Wr. Exp., Male]

"The Universe is an infinite emptiness, but there are planets in it. The Earth is also located in the middle of these planets." [Wr. Exp., Male]

"The Universe is a place full of stars, galaxies and planets. It's a huge place where everything is in it. It is black in color and there are glittering dots on it." [Wr. Exp. \& Int.-S1, Female]

"I think, the Universe is the space, the black, rounded area." [Int.-S2, Female]

"The universe is a huge place, including space, and I know that it is expanding.

The universe is bigger; it covers the space." [Int.-S3, Female]

"The universe is a very big place. As I know, it has no end. It's got everything in it. There are celestial bodies, the Sun, planets like Earth, Neptune and so on, Mars.

The stars are in the universe, as well." [Wr. Exp. \& Int.-S4, Female]

\section{Findings about the concept of the Sun}

The concept cartoon about the Sun is given in Figure 2.

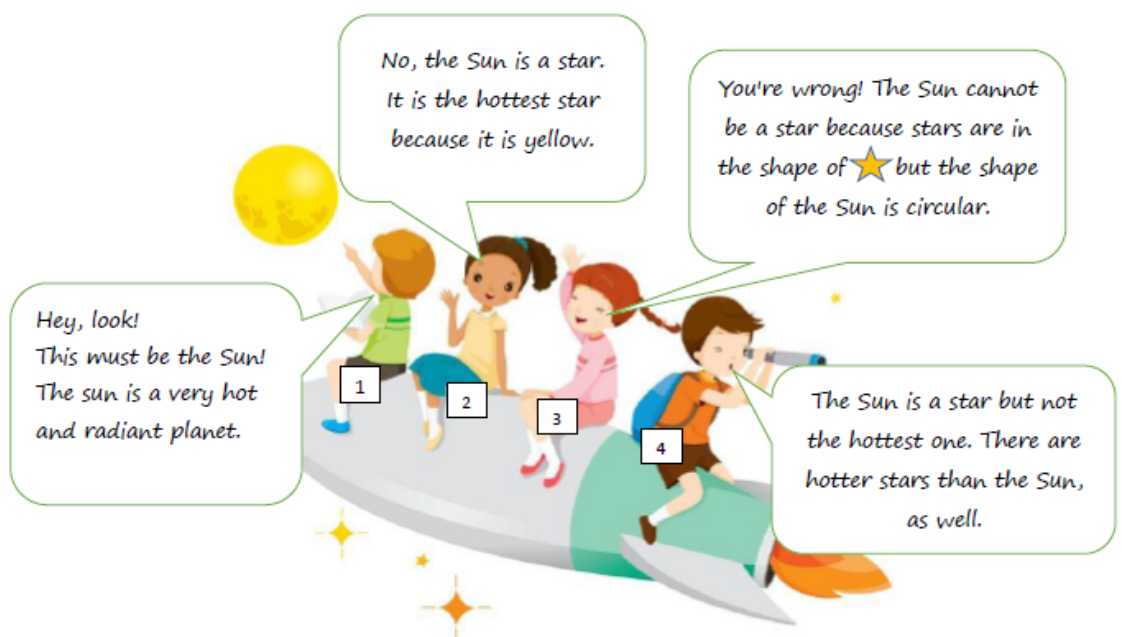

Figure 2. The concept cartoon about the Sun concept

In the concept cartoon about the Sun concept, only the $4^{\text {th }}$ expression was scientific, while others $\left(1^{\text {st }}, 2^{\text {nd }}\right.$ and $\left.3^{\text {rd }}\right)$ spanned misconceptions. Students' conceptual knowledge levels identified by 
the concept cartoon are given in Table 5.

Table 5. Students' conceptual knowledge levels about the Sun concept

\begin{tabular}{lll}
\hline Answer & $\mathrm{f}$ & $\%$ \\
\hline Understanding (Correct answer + Correct explanation) & 46 & 41.81 \\
Partial understanding (Correct answer + Partially correct explanation) & 15 & 13.63 \\
Misconception (Correct answer + Wrong explanation) & 14 & 12.72 \\
Misconception (Wrong answer + Correct explanation) & 23 & 20.90 \\
No understanding (Wrong answer + Wrong explanation) & 12 & 10.90 \\
\hline
\end{tabular}

As Table 5 shows, in the same way as the universe concept, $41.81 \%$ of the students selected the correct answer and brought out a scientific explanation about the Sun. $13.63 \%$ of the students, on the other hand, had partial understanding and $10.90 \%$ did not show understanding. The students, who did not show understanding, stated irrelevant responses like "the Sun is yellow" or "it gives vitamin D". It was found that $33.62 \%$ of the students developed misconceptions about the concept of the Sun. Among the misconceptions found in the written expressions and interviews, it was seen that some students defined the Sun as "a medium temperature planet" $(n=20)$, while some others defined it as "the hottest star" $(n=6)$. It was also interesting to see that some students stated that "the Sun revolved around the Earth" $(\mathrm{n}=6)$, or they (the Sun and the Earth) revolved around each other. It was seen in the interviews that students featured the Sun as "bright, yellow or yellowish, hot or the hottest, or layered". Some excerpts from their responses to open ended questions and interview questions are as follows:

"The Sun is a medium temperature planet." [Wr. Exp., Male]

"The Sun and Earth revolve around each other." [Int.-S3, Female]

"The Sun is very hot; I think it is the hottest planet." [Wr. Exp., Male]

"The Sun is the hottest star." [Wr. Exp., Female]

"The Sun is so bright and a yellowish star and it is the source of our life. If it wasn't for it, nothing would happen on the Earth. We get almost all our energy from the Sun. ... It is a star because it is too hot. ... It does not move, but all planets revolve around the Sun attached to particular rings. " [Int.-S1, Female]

"The Sun is a warm celestial body composed of layers. I know that it's hot. It is also a star. It warms us up. ... When we look at the Sun from here, we think that it is small; actually it is huge. ... It could be a star because it emits light. Besides, it doesn't move." [Int.-S2, Female]

"The Sun warms us up, a natural light source, giving us vitamin D. It is hot, - a medium temperature star-.. because I know that the blue and white ones are warmer. It gives light. The Sun revolves around both the Earth and itself." [Int.S3, Female]

"I know that the Sun is a star. It is hot. It is the biggest star in our world. But there are bigger ones which are not close to us. It is warm, bright, a star that warms us. It revolves around us. Without it, it's winter. I heard that stars are born and die." [Int.-S4, Female]

"It is a star that lights our Earth. It is hot. Yellow in color. It is also important for living things. It is the biggest star. There are explosions on it. There is no life because it is too hot." [Int.-S5, Female]

\section{Findings about the concept of Comet}

The concept cartoon about the comet concept is given in Figure 3. 


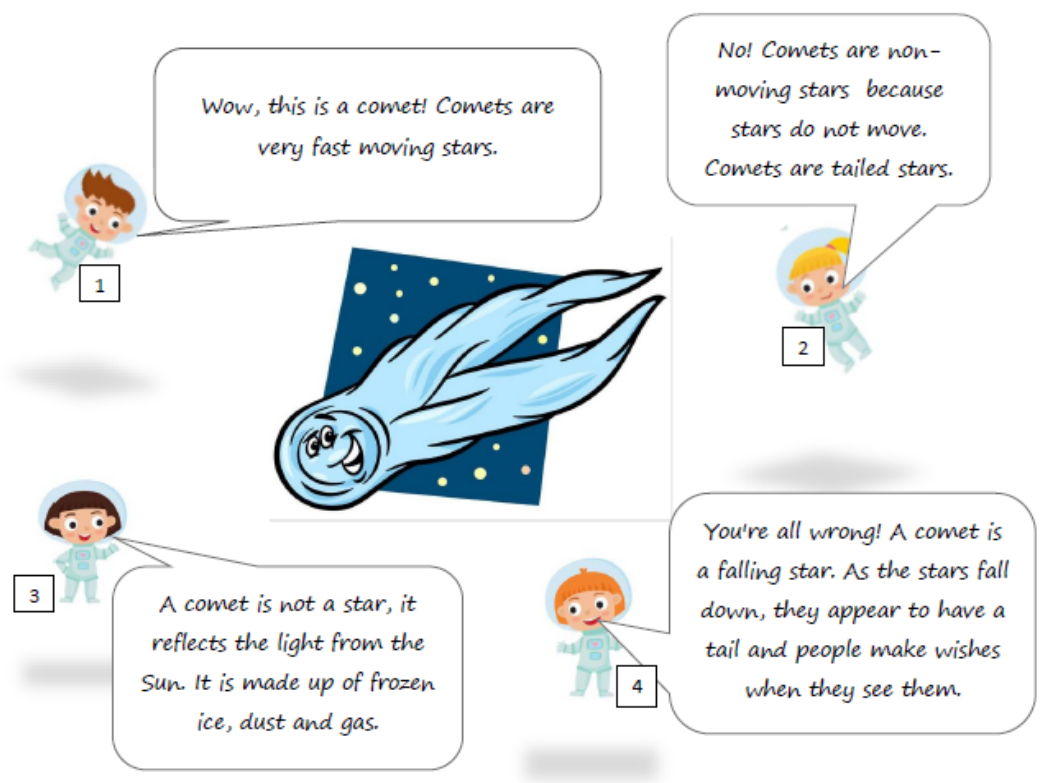

Figure 3. The concept cartoon about the comet concept

In the concept cartoon about the comet concept, only the $3^{\text {rd }}$ expression was scientific, while others $\left(1^{\text {st }}, 2^{\text {nd }}\right.$ and $\left.4^{\text {th }}\right)$ spanned misconceptions. Students' conceptual knowledge levels identified by the concept cartoon are shared in Table 6 .

Table 6. Students' conceptual knowledge levels about the comet concept

\begin{tabular}{lll}
\hline Answer & $\mathrm{f}$ & $\%$ \\
\hline Understanding (Correct answer + Correct explanation) & 22 & 20.00 \\
Partial understanding (Correct answer + Partially correct explanation) & 10 & 9.09 \\
Misconception (Correct answer + Wrong explanation) & 32 & 29.09 \\
Misconception (Wrong answer + Correct explanation) & 16 & 14.54 \\
No understanding (Wrong answer + Wrong explanation) & 30 & 27.27 \\
\hline
\end{tabular}

As presented in Table 6 , only $20 \%$ of the students selected the correct one among the expressions about comets and provided a scientific explanation. Almost ten percent, on the other hand, selected the correct answer without providing a scientific explanation or writing statements like "I know that they are not stars but I do not know exactly what they are". It was found that $27.27 \%$ of the students did not show understanding and when providing explanations to the answers, students usually stated explanations like "as its name suggests, it is a tailed star, a star with a tail (that is, "kuyruklu yıldız"; please see the Discussion part). Finally, a remarkable percentage of students $(43.63 \%)$ had misconceptions about the concept of comet. Among the most common misconceptions were defining comets as "images of dying stars falling from the sky" ( $n=35)$ or "falling stars that people make wishes as they see them" $(n=28)$. These findings suggest that students defined comets as stars and stated that they are either tailed, falling, dying or moving. Some excerpts from their responses to open ended questions and interview questions are as follows:

"When stars die, they fall down forming a tail behind. This happens because they fall down very fast." [Wr. Exp., Male]

"Stars have a lifetime. When they're done, they fall down and then they become comets." [Wr. Exp., Male] 
"When the stars move quickly, they form a tail. It happens in the speed of light." [Wr. Exp., Male]

"A comet is a glamorous star with a tail behind it. As far as I can see in the pictures, and in the book, there's a tail behind it, it's falling fast. ... As I told you, stars have a lifetime, they fall down as they die, because the gravity is strong. Behind them a tail is formed because they go too fast. ... Why do I think that a comet is a star? Because there are different types of stars. Some are brighter, some have gases around them, others have a tail like a fireball." [Int.-S1, Female]

"It's a falling star with colorful tails behind it. The tails are tied to the star and let it move." [Wr. Exp. \& Int.-S2, Female]

"Actually, there is no comet. We think as if they are comets because these stars fall down so fast. They're fast. They are normally, stars. ” [Int.-S3, Female]

"It has a tail; we can see it from the sky as it falls. A dying star falls to the ground; we see it falling. A falling star. Normally it doesn't move, but when it dies, it falls quickly when there is gravity or something, then it moves, normally it doesn't." [Int.-S4, Female]

\section{Findings about the concept of Constellation}

The concept cartoon about the constellation is given in Figure 4.

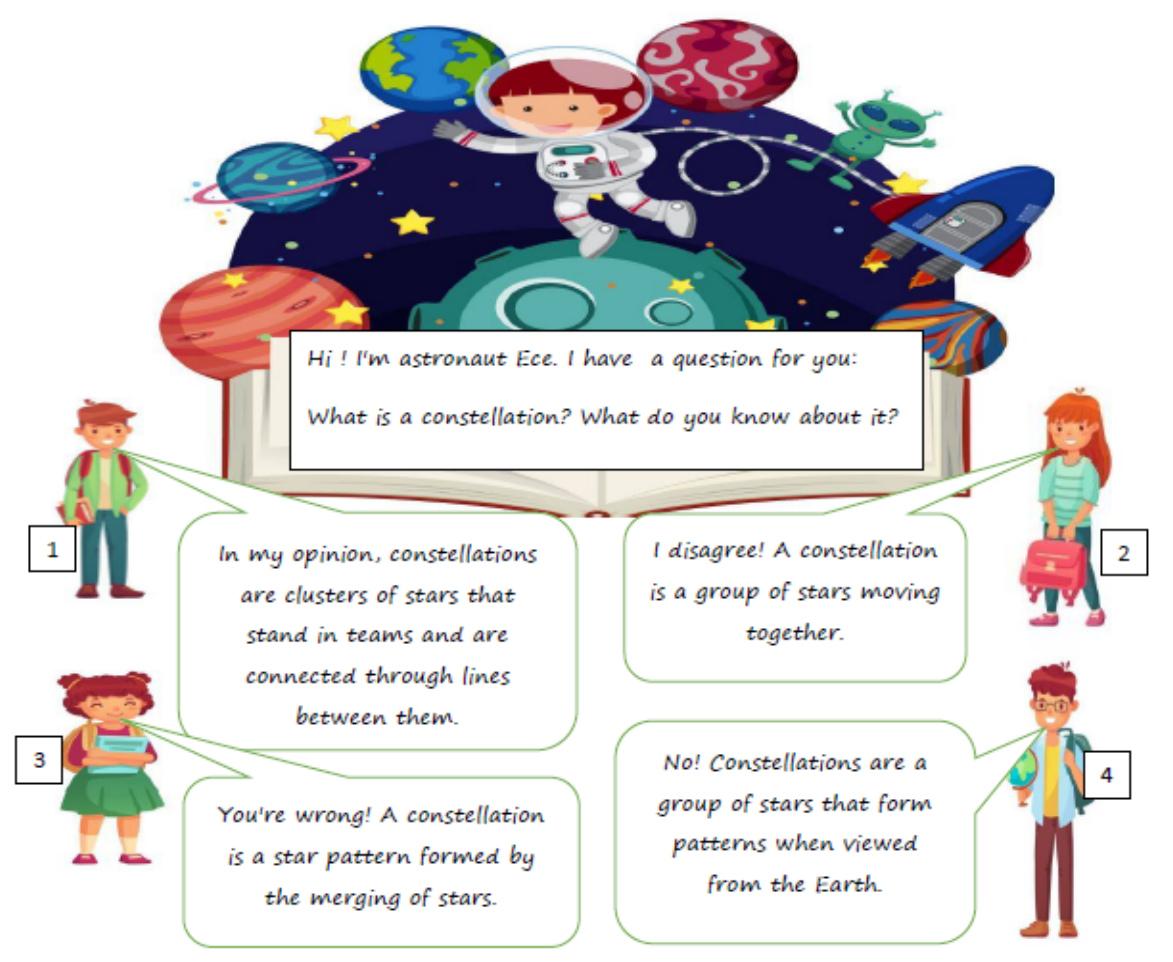

Figure 4. The concept cartoon about the constellation concept

In the concept cartoon about the constellation concept, only the $4^{\text {th }}$ expression was scientific, while others $\left(1^{\text {st }}, 2^{\text {nd }}\right.$ and $\left.3^{\text {rd }}\right)$ spanned misconceptions. Students' conceptual knowledge levels identified by the concept cartoon are provided in Table 7 . 
Table 7. Students' conceptual knowledge levels about the constellation concept

\begin{tabular}{lll}
\hline Answer & $\mathrm{f}$ & $\%$ \\
\hline Understanding (Correct answer + Correct explanation) & 20 & 18.18 \\
Partial understanding (Correct answer + Partially correct explanation) & 11 & 10 \\
Misconception (Correct answer + Wrong explanation) & 20 & 18.18 \\
Misconception (Wrong answer + Correct explanation) & 10 & 9.09 \\
No understanding (Wrong answer + Wrong explanation) & 49 & 44.54 \\
\hline
\end{tabular}

Constellation was the concept that the students who participated in this study had the most limited understanding of amongst the others viz. the Sun, the Universe, and comets. As can be seen in Table 7, only $18.18 \%$ of the students marked the correct answer, while almost half of them $(44.54 \%)$ did not show understanding. These students were unable to provide an explanation or, simply wrote assertions like "I do not know". Moreover, it was found that $27.27 \%$ of the students had misconceptions about the concept. Students having misconceptions described constellations as collection of stars connected by lines between them $(n=46)$, or group of stars moving together $(\mathrm{n}=22)$. They also thought that constellations actually look like animals. Some excerpts from their responses to open ended questions and interview questions are as follows:

"Constellations are the stars that are connected to each other." [Wr. Exp., Male]

"They are the stars standing together." [Wr. Exp., Male]

"They move as a team. People name them." [Wr. Exp., Male]

"They move by forming a group." [Wr. Exp., Female]

"The interconnected stars are called constellations, and the zodiac signs are constellations. They have shapes." [Wr. Exp., Female]

"They are composed of dots forming shapes. They have names like Lion, Taurus." [Wr. Exp., Female]

"Stars that form shapes are called constellations. Zodiac signs, for example, are constellations." [Wr. Exp., Male]

"Constellations, you know, they're likened to, like, all their shapes are likened to animals. When they unite, they form something and form a shape. I think, they are connected to each other; when it is drawn, shapes are coming out. Leo or something." [Int.-S1, Female]

"The grouped stars... They move together. They form shapes. Various shapes are formed, Big Dipper, Little Dipper... These are what I know. Ancient people used to combine those shapes with lines and used to liken them to something. Then they named them." [Int.-S4, Female]

\section{Discussion and Conclusion}

The aim of this study was to investigate seventh grade students' misconceptions about a number of basic astronomy concepts, namely, the Universe, the Sun, comets and the constellations. The findings reported above indicated that students hold a series of misconceptions on the related topics in basic astronomy (see Table 8).

Table 8. Students' misconceptions about basic astronomy concepts

\begin{tabular}{llll}
\hline Concept & Misconceptions & f & $\%$ \\
\hline \multirow{3}{*}{ The Universe } & The Universe is the emptiness outside the Earth. & 17 & 15.4 \\
& The center of the Universe is the Earth. & 12 & 10.9 \\
& The Universe is the planet Earth where we live in. & 11 & 10 \\
\hline
\end{tabular}




\begin{tabular}{llll}
\hline \multirow{3}{*}{ The Sun } & The Sun is a medium temperature planet. & 20 & 18.1 \\
& The Sun revolves around the Earth. & 6 & 5.4 \\
& The Sun is the hottest star. & 6 & 5.4 \\
\hline \multirow{2}{*}{ Comets } & Comet is the image of dying stars as they fall from the sky. & 35 & 31.8 \\
& A comet is a tail and a star that we wish to glide with. & 28 & 25.4 \\
\hline \multirow{2}{*}{ Constellations } & Constellations are stars that are connected by lines. & 46 & 41.8 \\
& Team stars are stars that circulate in teams. & 22 & 20 \\
\hline
\end{tabular}

Findings showed that students had misconceptions mostly about comets (See Figure 5). Defining a comet as an image of a dying star falling from the sky was quite common among the students. Another important issue found in this research was that, almost half of the students had limited understanding about constellations. The number of students who defined constellations as a group of stars connected by lines among them was as a matter of fact considerable.

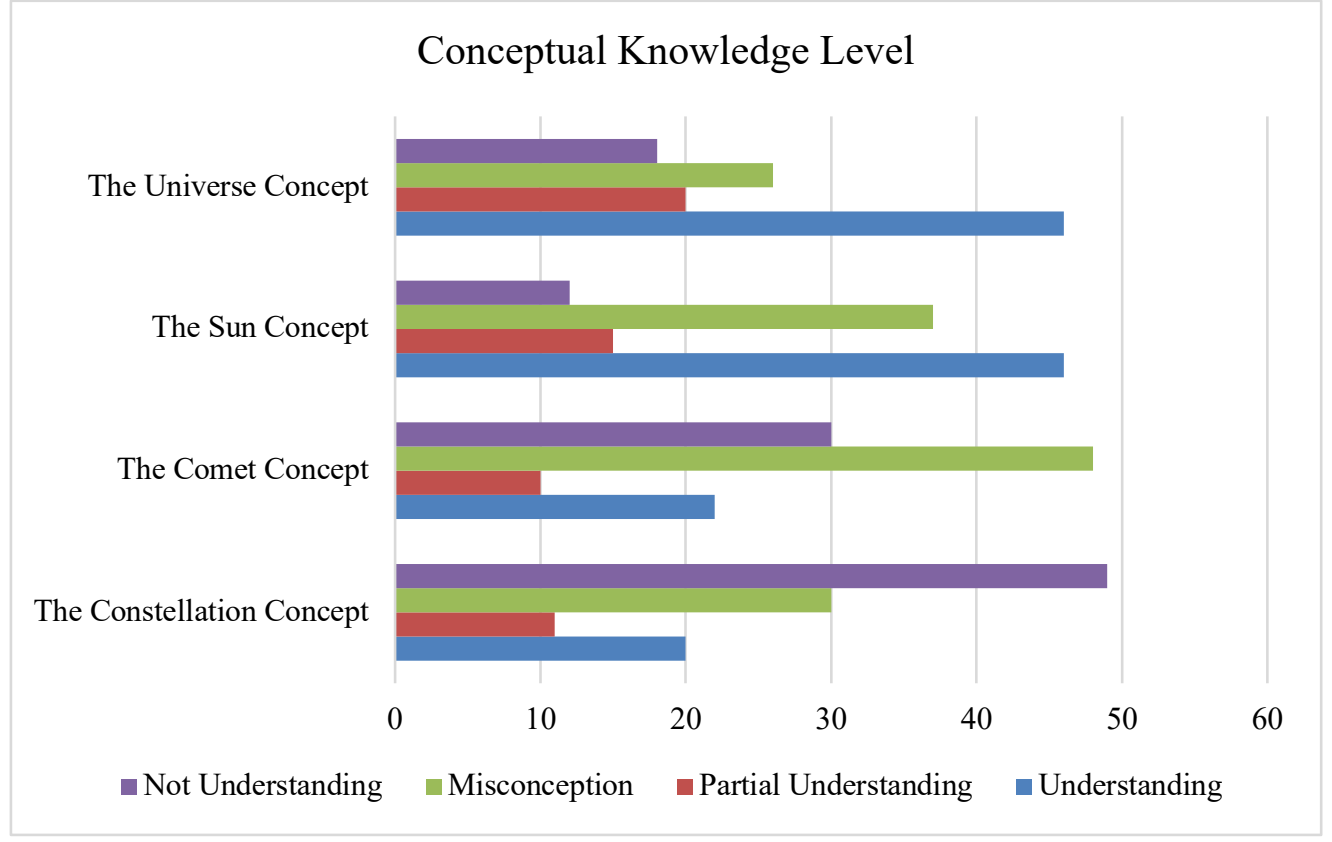

Figure 5. Students' conceptual knowledge levels about the astronomy concepts

Although basic astronomy concepts such as the Sun, stars and planets are presented to students beginning from early ages, findings showed that students did not have any sufficient knowledge, instead they produced alternative conceptions. This result was quite consistent with previous studies. In these studies, it was reported that students held several misconceptions like defining shooting stars as visible comets (Göncü, 2013; Korur, 2015), characterizing the Sun as the biggest celestial body (Korur, 2015) but not as a star (Sadler et al., 2010), defining the Universe as the infinite space outside the Earth (Ekiz \& Akbaş, 2005; Korur, 2015) and labeling the Sun as the center of the Universe (Göncü, 2013).

As Comins (1998) identified, there may be varying origins of misconceptions. Among them are factual misinformation sources like teachers, adults and textbooks, incomplete/inaccurate information reported in the media, misconceptions created in cartoons and science fiction, mythical concepts that we accept by virtue of faith, the imprecision in language, personal cosmology knowledge, incomplete understanding of scientific process and scientists, incomplete reasoning, misinterpreting sensory information, inaccurate and incomplete observations and a lack of common sense of astronomy, and anthropomorphizing astronomical 
concepts (Comins, 1998). Before starting their formal education, young children are exposed to several scientific concepts through cartoons. The rise of the digital era provided them with countless science-related cartoons to watch. Although they seem to be helpful in introducing basic scientific concepts to children, these cartoon depictions of science concepts either through simplification, anthropomorphizing or through other means, or the misrepresentation of the concepts for the sake of entertainment and fun may lead to the formation of misunderstandings about them. Young children are not developmentally grown enough to differentiate the artificial context in the cartoon from the reality and to reason about them. Students at elementary level may have difficulty in forming scientifically acceptable mental models. The narrative nature of abstract or hard-to-examine concepts forces students to form an understanding of these in their own mind. Thereupon, astronomy issues should be organized in accordance with learners' developmental levels (Koçer, 2002). Professional revision of textbooks and related curriculum materials may help avoid factual misinformation through school-related sources of misconceptions. Constructivist learning strategies like direct observations and experiences may assist students in forming scientifically acceptable understandings. Teachers are likely to transfer their misconceptions to their students, as well (Akgün, 2009). Their understanding is really effective on students' ability to learn science; to illustrate, a superficial understanding spotted leads teachers to emphasize the memorization of isolated facts and some are afraid of encouraging students to move beyond the their knowledge in a creative and innovative classroom atmosphere (Gess-Newsome, 2001, as cited in Brunsell \& Marcks, 2005). To that end, science teachers should be well equipped with the knowledge of astronomy concepts during their undergraduate education. Misconceptions should be eliminated, and teachers' content knowledge should be strengthened while giving them more place in the curriculum. In Turkey, there are several science courses (including an astronomy must course) in science education undergraduate program but research shows that science teachers still have poor a understanding of astronomy (Bektaşl1, 2013; Emrahoğlu \& Öztürk, 2009; İyibil, 2010; Kanli, 2014; Trumper, 2001). In that case, it would be fair to state that more emphasis needs to be put on teacher training programs. Within these programs, the content should be kept up to date and misconceptions should be prevented. In Turkish language, the term "comet" is "kuyruklu yıldiz" whose Turkish translation reads "tailed star". Similarly, "constellation" is "takım yıldızı" in Turkish which reads "star cluster/group". The Turkish meanings of these two terms, whence, may lead to misconceptions in students' (and even adults') minds. Throughout their education, students should learn the scientific meanings of these words and the formation of misconceptions should be prevented.

Eliminating students' misconceptions is challenging but educational strategies play a crucial role in this process. Since misconceptions are resistant to change, the first step in eliminating students' misconceptions is to determine their existing understandings. To do so teachers can test students' prior knowledge by using different teaching methods and techniques prior to the presentation stage. Plenty of methods can be used to determine the misconceptions. Modeling, concept maps, concept cartoons are effective methods for determining these and eliminating such situations. The findings of the current study demonstrated that concept cartoons are practical instruments to detect misconceptions. The use of concept cartoons prior to instruction can provoke the understandings which in turn lead the learning activities. Concept cartoons also make students active in learning by enhancing their motivation to discuss and question their and others' understanding. This creates a chance to bring forward their ideas for discussion. Concept cartoons can also be used after the presentation stage to remove misconceptions. 


\section{Recommendations}

The current study has some limitations. It confines itself to investigating the misconceptions of a sample of 110 seventh-grade students in Alanya, who were selected conveniently. These issues limit the generalizability of the study to a national population. From this point, research can be done with a larger sample from different areas. Moreover, in the study, it was attempted to determine the misconceptions about four of the basic astronomy concepts. Similar studies can be done to see if there are misconceptions about other astronomy concepts. Additionally, an experimental research using concept cartoons can be done to detect misconceptions as well as to eliminate them.

\section{Acknowledgements}

A part of this study was presented at $10^{\text {th }}$ International Congress of Research in Education (ULEAD), April 20-22, 2019, Alanya/Antalya, Turkey.

\section{References}

Adams, J.P. \& Slater, T.F. (2000). Astronomy in the national science education standards. Journal of Geoscience Education, 48(1), 39-45.

Akgün, A. (2009). The relation between science student teachers' misconceptions about solution, dissolution, diffusion, and their attitudes toward science with their achievement. Education and Science, 34(154), 26-36.

Albanese, A., Danhoni Neves, M.C., \& Vicentini, M. (1997). Models in science and in education: A critical review of research on students' ideas about the earth and its place in the universe. Science and Education, 6, 573-590.

Anderson, D.L., Fisher, K.M., \& Norman, G.J. (2002). Development and evaluation of the conceptual inventory of natural science. Journal of Research in Science Teaching, 39, 952-978.

Arıkurt, E. (2014). Comparison of the effect of concept cartoons and conceptual change texts on the achievement, conceptual changes and attitudes of 7 th grade students.Unpublished Master's Thesis. Giresun University, Giresun.

Atwood, R.K. \& Atwood, V.A. (1996). Preservice elementary teachers' conceptions of the causes of seasons. Journal of Research in Science Teaching, 33, 553-563.

Bektaşl1, B. (2013). The development of astronomy concept test for determining preservice science teachers' misconceptions about astronomy. Education and Science, 38(168), 362-372.

Bell, B. (1985). Students' ideas about plant nutrition: What are they?. Journal of Biological Education 19, 213-218.

Bostan, A. (2008). Different age group students' thoughts on some basic concepts of astronom. Unpublished Master's Thesis. Balıkesir University, Balıkesir.

Boyes, E. \& Stanisstreet, M. (1991). Misconceptions in first-year undergraduate science students about energy sources for living organisms. Journal of Biological Education, 25(3), 208-213.

Brunsell, E. \& Marcks, J. (2005). Identifying a baseline for teachers' astronomy content knowledge. Astronomy Education Review, 3(2), 38- 46.

Chaisson, E. \& McMillan, S. (1999). Astronomy Today (3rd Ed.). Prentice-Hall, New Jersey.

Comins, N.F. (1998). in New Trends in Astronomy Teaching, IAU Colloquium 162, Ed. L. Gouguenheim, D. McNally \& L.R. Percy. Cambridge University Press.

Demir, Y. (2008). The use of concept cartoons in determining misconceptions. Unpublished Master's Thesis, Ataturk University, Erzurum. 
Dreyfus, A. \& Jungwirth, E. (1988). The cell concept of $10^{\text {th }}$ graders: Curricular expectations and reality. International Journal of Science Education, 10(2), 221-229.

Driver, R., Squires, A., Rushworth, P., \& Wood-Robinson, V. (1994). Making Sense of Secondary Science: Research into Children's Ideas. London \& New York: Routledge.

Ekiz, D. \& Akbaş, Y. (2005). 6th grade students' level of understanding and misconceptions about astronomy concepts. Milli Ë̆itim Dergisi, 165, 61-78.

Emrahoğlu, N. \& Öztürk, A. (2009). A longitudinal research on the analysis of the prospective science teachers' level of understanding the astronomical concepts and their misconceptions. Çukurova University Journal of the Institute of Social Sciences, 18(1), 165-180.

Frede, V. (2006). Pre-service elementary teacher's conceptions about astronomy. Advances in Space Research, 38(10), 2237-2246.

Gess-Newsome, J. (2001). The Professional Development of Science Teachers for Science Education Reform: A Review of Research, In Professional Development Planning and Design, Ed. J. Rhoton \& P. Bowers. Arlington, VA: NSTA Press.

Göncü, Ö. (2013). Determining of astronomical misconception in fifth and seventh grade students. Unpublished Master's Thesis. Mehmet Akif Ersoy University, Burdur.

Griffiths, A. K. \& Grant, B.A.C. (1985). High school student's understanding of food webs: Identification of learning hierarchy and related misconceptions. Journal of Research in Science Teaching, 22(5), 421-436.

Güneş, G. (2010). The analyze of the relation between astronomy knowledge with the nature of science and the astronomy self-efficacy belief of pre-service teachers. Unpublished Master's Thesis, Çukurova University, Adana.

Hannust, T. \& E. Kikas, E. (2007). Children's knowledge of astronomy and its change in the course of learning. Early Childhood Research Quarterly, 22(1), 89-104.

Haslam, F. \& Tregust, D.F. (1987). Diagnosing secondary students' misconceptions of photosynthesis and respiration in plants using a two-tier multiple choice instrument. Journal of Biological Education, 21, 203-211.

Ivankova, N.V., Creswell, J.W. \& Stick, S.L. (2006). Using mixed-methods sequential explanatory design: From theory to practice. Field Methods, 18(1), 3-20.

İyibil, Ü.G. (2010). The analysis of the understanding levels and mental models of candidate teachers studying at different departments about basic astronomy concepts. Unpublished Master's Thesis, Karadeniz Technical University, Trabzon.

Jones, B.L., Lynch, P.P. \& Reesink, C. (1987). Children's conceptions of the earth, sun and moon. International Journal of Science Education, 9, 43-53.

Kanl1, U. (2014). A study on identifying the misconceptions of pre-service and in-service teachers about basic astronomy concepts. Eurasia Journal of Mathematics, Science \& Technology Education, 10(5), 471-479.

Kaplan, G. (2011). Ways of perception of basic astronomy terms of 5th grade primary school students with/without mental retardation. Unpublished Master's Thesis, Abant İzzet Baysal University, Bolu.

Keogh, B., Naylor, S. (1996, October). Teaching and learning in science: A new perspective. Bera Conference, University of Lancester, UK.

Kikas, E. (1998). The impact of teaching on students' definitions and explanations of astronomical phenomena. Learning and Instruction, 8, 439-454.

Kinchin, I.M. (2000). From 'ecologist' to 'conceptual ecologist': The utility of the conceptual ecology analogy for teachers of biology. Journal of Biological Education, 34(4), 178183. 
Koca, E.E. (2019). Revealing middle school students' misconceptions about basic astronomy concepts through drawing method. Unpublished Master's Thesis. Y1ldiz Technical University, İstanbul.

Koçer, D. (2002, September). The importance and necessity of astronomy education in Turkey, and the things to do. V. National Congress of Science and Mathematics Education, METU, Ankara.

Korur, F. (2015). Exploring seventh-grade students' and pre-service science teachers' misconceptions in astronomical concepts. Eurasia Journal of Mathematics, Science \& Technology Education, 11(5), 1041-1060.

Kurnaz, M.A. (2012). Determining students' comprehension of the star, comet, and constellation concepts. Journal of Abant İzzet Baysal University Faculty of Education, 12(1), 251-264.

Kurnaz, M.A. \& Değirmenci, A. (2012). 7. Mental models of $7^{\text {th }}$ grade students on sun, earth and moon. Elementary Education Online, 11(1), 137-150.

Kurnaz, M.A., Bozdemir, H., Altunoğlu, B.D. \& Çevik, E.E. (2016). Analysis of national articles published in astronomy subject areas. Journal of Erzincan University Faculty of Education, 18(2), 1398-1417.

Kusumaningrum, I.A., Ashadi, \& Indriyanti, N.Y. (2018). Concept cartoons for diagnosing student's misconceptions in the topic of buffers. Journal of Physics Conference Series, 1022(1).

Lawson, A.E. \& Thompson, L.D. (1988). Formal reasoning ability and misconceptions concerning genetics and natural selection. Journal of Research in Science Teaching, 25, 733-746.

Lewis, J., Leach, J. \& Wood-Robinson, C. (2000). All in the genes? -Young people's understanding of the nature of gene. Journal of Biological Education, 34(2), 74-80.

Marché, J. D. (2002). Mental discipline, curricular reform, and the decline of U. S. astronomy education, 1893-1920. Astronomy Education Review, 1(1), 58-75.

Mestre, J. (1987). Why should mathematics and science teachers be interested in cognitive research findings? Academic Connections, 3-11.

Miles, M.B. \& Huberman, A.M. (1994). Qualitative data analysis: A sourcebook of new materials. (2nd Ed.). Thousand Oaks, CA: Sage Publications.

Ministry of National Education [MoNE] (2018). Fen bilgisi dersi öğretim programı (Elementary Science Curriculum]. Ankara: T.C. Milli Eğitim Bakanlığı, Talim ve Terbiye Kurulu Başkanlığı.

Munson, B.H. (1994). Ecological misconceptions. Journal of Environmental Education 25, 3035 .

National Research Council, (1996). National Science Education Standards: Washington, DC, National Academy of Sciences Press.

Naylor, S. \& Keogh, B. (2013). Concept cartoons: what have we learnt? Journal of Turkish Science Education, 10(1), 3-11.

Nussbaum, J. (1979). Children's conception of the earth as a cosmic body: A cross age study. Science Education, 63(1), 83-93.

Odom, A. L. \& Barrow, L. H. (1995). Development and application of a two-tier diagnostic test measuring college biology students' understanding of diffusion and osmosis after a course of instruction. Journal of Research in Science Teaching, 32, 45-61.

Oliva, J. M. (1999). Structural patterns in students' conceptions in mechanics. International Journal of Science Education, 21, 903-920.

Oliva, J. M. (2003). The structural coherence of students' conceptions in mechanics and conceptual change. International Journal of Science Education, 25, 539-561. 
Onwuegbuzie, A.J. \& Leech, N.L. (2005). On becoming a pragmatic researcher: The importance of combining quantitative and qualitative research methodologies. International Journal of Social Research Methodology, 8(5), 375-387.

Pashley, M. (1994). A-level students: their problems with gene and allele. Journal of Biological Education, 28, 120-127.

Posner, G.J., Strike, K.A., Hewson, P.W. \& Gertzog, W.A. (1982). Accommodation of a scientific conception: Toward a theory of conceptual change. Science Education, 66, 211-227.

Sadler, P. M. (1998). Psychometric models of student conceptions in science: Reconciling qualitative studies and distractor-driven assessment instruments. Journal of Research in Science Teaching, 35(3), 265-296.

Sanders, M. (1993). Erroneous ideas about respiration: The teacher factor. Journal of Research in Science Teaching, 30(8), 919-934.

Scharp M. \& Sanders, M.L. (2019). What is a theme? Teaching thematic analysis in qualitative communication research methods. Communication Teacher, 33(2), 117-121.

Seymour, J. \& Longden, B. (1991). Respiration - that's breathing isn't it? Journal of Biological Education, 25 (3), 177-183.

Sezen, F. (2002). Understanding level and misconceptions of the astronomical concepts of 7th grade students. Unpublished Master's Thesis, Karadeniz Technical University, Trabzon.

Taşcan, M., \& Ünal, İ. (2015). The importance of astronomy education and evaluation of education programs in Turkey. Journal of Buca Faculty of Education, 40, 25-37.

Treagust, D.F. \& Smith, C.L. (1989). Secondary students' understanding of gravity and the motion of planets. School Science and Mathematics, 89(5), 380-391.

Trowbridge, J. E. \& Mintzes, J. J. (1985). Students' alternative conceptions of animals and animal classification. School Science and Mathematics, 85, 305-316.

Trumper, R. (2000). University students' conceptions of basic astronomy concepts. Physics Education, 35(1), 9-15.

Trumper, R. (2001). Assessing students' basic astronomy conceptions from junior high school through university. Australian Science Teachers Journal, 41, 21-31.

Trundle, K.C., Atwood, R.K. \& Christopher, J.E. (2002). Preservice elementary teachers' conceptions of moon phases before and after instruction. Journal of Research in Science Teaching, 39(7), 633-658.

Waheed, T. \& Lucas, A. M. (1992). Understanding interrelated topics: Photosynthesis at age 14. Journal of Biological Education, 26, 193-200.

Yip, D. Y. (1998). Teachers' misconceptions of the circulatory system. Journal of Biological Education, 32(3), 207-216.

Zeilik, M., Schau, C. \& Mattern, N. (1998). Misconceptions and their change in university astronomy courses. The Physics Teacher, 36, 104-107.

Zeilik, M. (2002). Birth of the astronomy diagnostic test: Prototest evolution. Astronomy Education Review, 1(2), 46. 